\title{
SCIENCE AND MATH TEACHERS' COLLABORATION: HOW TO DEVELOP IT SEEKING PUPIL'S SUCCESS AT SCHOOL
}

\author{
Vincentas Lamanauskas \\ University of Šiauliai, Lithuania \\ E-mail: v.lamanauskas@ef.su.It
}

The importance of science and technology is obviously increasing. Such spheres as biotechnology, environmental security, biochemistry, synthetic biology, neurobiology and other have been strongly affected and even changed by science and technology progress. And that affect is growing. It is paradoxical, but over the last decade a decreased youth interest in science and technologies has been observed in many world countries. One of the first serious research studies on that question was initiated and carried out by IOSTE (International Organization for Science and Technology Education, http://ioste.nmmu.ac.za/). The research "The Relevance of Science Education", http://roseproject.no/) showed that there are essential differences among various countries. One of the most worrying problems is, that in so-called developed countries (e.g., Japan, Norway, Finland, Great Britain and other) the youth interest in science and technologies is poor, the biggest part of youth do not relate their career with science and technologies. Whilst, in so-called developing countries (e.g., Uganda, Philippines, Trinidad and Tobago, Botswana and other) the youth relate their future career with science and technology development and think that this is a guarantee for better life and success. The first international comparative research was carried out in 2004 and repeated in 2008. The results, basically, were similar. Later, the researchers carried out various comparative research studies applying additional variables, for example, (Human Development index, HDI). Again, the same tendency was confirmed, to be more precise, an inverse correlation relationship was obtained. The countries, whose HDI is high, the youth's interest in science and technologies is poor, and on the contrary, in the countries whose HDI is relatively low, the youth are interested in science and technology development. Though, these results are quite well known in academia, however, they are very important from the political and practical point of view (Lamanauskas, 2014). PISA and TIMMS research studies showed the same tendencies as well. Though the youth in developed countries understand the importance of science and technologies, however, this does not mean a lot to them. One of the most probable causes of such situation is, that at school it is not shown or (insufficiently shown) the importance of science and technologies for future career possibilities. Why isn't this shown? Again, a lot of things determine such situation. First of all, science subjects and especially math are taught at school referring to formulas, theorems, blindly following the textbooks. Apparently, there is a lack of practical examples, real situations and problem solutions. It is understandable, that this requires much bigger resources - both material and intellectual. Thus, it is necessary to increase the possibilities for pupils to get acquainted with the practical appliance of sciences and math. This includes the attendance of university, plant laboratories, museums and other.

Over the latter several decades, in many European countries, it has been sought to improve science teaching both in comprehensive and higher schools. It is stated, that it is necessary to change traditional, didactic system to constructivist (Solomon, 1993; Zoller, Tsaparlis, 
PROBLEMS

OF EDUCATION

IN THE $21^{\text {st }}$ CENTURY Volume 62,2014

1997). It is grounded by various researches, that the mathematics concepts are critical for students' understanding of science (Schwols, Miller, 2012). Of course, it is a bilateral benefit. Both subjects are mastered better. Also, the other ways are sought to improve science and technological education of young generation. Recently, a lot of different level projects have been carried out, seeking to reveal the causes of such poor interest, on the other hand, it is sought to improve didactic instruments, used in comprehensive schools. Since 01-01-2013 a new European Union $7^{\text {th }}$ Framework Programme (FP7/2013-2017) project "Mascil" has been started. The project unites 18 partners, science and mathematics teaching, common education, electronics learning and journalism experts from 13 countries participate in it (http://portalas.emokykla.lt/naujienos/ Puslapiai/Naujiena11963.aspx). The main aim of the project is to develop inquiry-based science teaching. However, we think, it is not enough. Science education covers a wider content and context. It is necessary to develop scientific research activity. This is not only various research studies. Such activity includes project preparation and realisation, student involvement in a non formal science education structure activity, participation in various contests and Olympiads and other. In other words, attention is drawn not only to the pupils' demonstrating poor interest, but also to the gifted, talented pupils, interested in science and technologies.

Education practice shows, that despite certain science and math teachers' collaboration, it remains insufficient and very often inefficient in the meaning of pupils' achievements. It is obvious, that math teachers use scientific context doing math tasks. In their own way, science teachers use mathematics explaining chemistry, physics, biology laws and regularities or doing tasks. The problem is that teachers usually work individually; there is little of integrated activity. A wider and deeper collaboration is noticed in the science teachers' group. Math and science subject teachers collaborate much less (Lamanauskas, Šlekiené, Ragulienė, 2014).

Since 2013, an international project "Materials for Teaching Together: Science and Mathematics Teachers collaborating for better results" is being carried out. More about project and its realisation results one can find http://math.unipa.it/ grim/Prog_MaT2SMc_2014/ Home_Prog_MaT2SMc.html. An international project $\mathrm{MaT}^{2} \mathrm{SMc}$ is one more tribute to science and math teachers'qualification improvement, science education process quality strengthening. This project is carried out according to Lifelong programme, EU LLP Comenius project. It is sought to prepare concrete materials (scenarios of lessons and other educational activities), which could be used by teachers. It is oriented to science and math teachers' collaboration. Such material is supposed to be published and made freely available to all interested. Attention has to be paid, that such material is prepared by various country specialists; thus, concrete educational experience in one way or another will integrate in it.

Speaking about science and math teachers' collaboration, several important questions arise:

- How to develop teachers' collaboration seeking pupil's success at school?

- How to plan and project collaboration process?

- How to successfully collaborate seeking the pupils' progress?

- How to organise collaborative nets seeking teachers' work and pupils' educational success?

- How to rally collaborating teachers?

It wouldn't be easy to find the right and clear answers. However, it is obvious, that collaboration means a more qualitative final result. Collaboration, first of all, can be understood as a new space in which differences can be perceived and accepted as new possibilities. Traditionally, the teachers work individually; they mostly take care of their own subject. Collaborating, individual teacher's competencies are undoubtedly deepened and broadened; pupils' subject and inter-subject competence education is assured. It is hopeful that, being educational environment saturated with ICT in the latter years, new possibilities open for collaboration. Not only willingness of the teachers themselves, interest in collaboration, seeking education effective- 
ness in this way, is important. As B. Johnson claims (2014), "the school administrator is a critical factor in successful math and science teacher collaboration".

Teachers' collaboration is undoubtedly important. First of all, it is solving of various didactic problems performing together. Hereby, the abilities of this sphere are developed. Secondly, collaboration encourages the exchange of good educational experience, strengthens the trust among specialists of various spheres. Collaborating, the possibilities to organise common educational projects, to generate innovative educational ideas, to seek for closer integration of science and math, significantly arise. It is obvious, that mathematics is defined as a very important science and technology tool. Science and math teachers' collaboration in the educational process would strengthen not only professional teachers' competence, but would develop collaboration abilities, which are very important seeking much more qualitative pupils' science and technology education. It would be worth promoting more exhaustive educational research studies on this question and on the basis of them to prepare practical recommendations.

\section{References}

Johnson, B. (2014). Successful math and science teacher collaboration: The administrator's role. Edutopia / What Works In Education. Retrieved December 6, 2014, from http://www.edutopia.org/blog/ successful-math-and-science-teacher-collaboration-administrators-role-ben-johnson

Lamanauskas, V., Šlekienė, V., Ragulienè, L. (2014). Gamtos mokslų ir matematikos mokytojų bendradarbiavimas: "MaT ${ }^{2} \mathrm{SMc}$ " projektas [Natural Science and Mathematics Teachers Collaboration: Project "MaT²SMc"]. Gamtamokslinis ugdymas bendrojo lavinimo mokykloje - 2014 / Natural Science Education in a Comprehensive School - 2014, XX, 88-95.

Lamanauskas, V. (2014). Gamtos mokslų dalykų ir matematikos mokytojų bendradarbiavimas [The importance of natural science and mathematics teachers collaboration]. Gamtamokslinis ugdymas / Natural Science Education, 2 (40), 4-6.

Schwols, A., Miller, K. B. (2012). Identifying mathematics content and integrating it into science instruction. Science Scope, 36 (1), 48-52.

Solomon J. (1993). The social construction of children`s scientific knowledge. In.: P. J. Black, A. M. Lucas (Eds.), Children 's informal ideas in science. London: Routledge.

Zoller U., Tsaparlis, G. (1997). HOCS-LOCS students: The case of chemistry. Research in Science Education, 27, 117-130.

Received: November 10,2014 Accepted: December 18, 2014

Vincentas Lamanauskas PhD., Professor, Siauliai University, Natural Science Education Research Centre, 25-119 P. Višinskio Street, LT- 76351, Siauliai, Lithuania.

E-mail: v.lamanauskas@ef.su.It, lamanauskas@lamanauskas.puslapiai.It

Website: http://www.lamanauskas.puslapiai.lt/

Facebook: https://www.facebook.com/ScientiaEducologica 